\title{
MARKET PARTICIPATION AND FOOD SECURITY OF CASSAVA FARMERS IN RURAL SOUTH WEST NIGERIA
}

\author{
Adekemi Adebisola Obisesan ${ }^{\bowtie}$ \\ Federal University of Technology, Nigeria
}

\begin{abstract}
Gaining better market access is a concern to smallholder farmers in Africa. This study analyzed the market participation and food security among cassava farmers in South West Nigeria. Multi-stage sampling was employed in the selection of respondents. Data were analyzed using descriptive statistics, Foster-Greer-Thorbecke (FGT) indices, and Tobit and logit regression models. The extent of market participation among the farmers was found to be $0.56 \pm 0.13$. The level of education, off-farm income source, membership of an association, years of experience, access to market information, age and transportation costs significantly influenced the extent of market participation. At the food insecurity line of NGN 20,132.20 per annum, $61.53 \%$ of cassava farmers were food insecure. Food insecurity is significantly affected by the extent of market participation, gender, access to credit, off-farm income source, yield, household size, primary occupation, household income and access to market information. Therefore, the government and other stakeholders should devote attention to factors that increase market participation and food security among the farmers. In Nigeria, the cassava transformation project should not be limited to the provision of improved production technologies but needs to be extended to storage and marketing strategies in order to provide the farmers with some guidance on how to deal with market glut.
\end{abstract}

Keywords: cassava, market access, food insecurity, Rural Nigeria

\section{INTRODUCTION}

The importance of the agricultural sector in a developing economy cannot be overemphasized. The sector is populated by small holders responsible for over $90 \%$ of the total output. Over half of the farmers produce only food crops, including cassava (IFAD, 2010), an important source of food for about one third of the sub-Saharan population (IITA, 2003). It has the potential to boost farm incomes, close the food gap as well as reduce rural and urban poverty (Nweke et al., 2001). With an annual output of 53 million tons, Nigeria is the world's leading producer of cassava (FAO, 2013). In the rural economy of southern agro-ecological zones, cassava plays a crucial role and is becoming increasingly important in other parts of Nigeria (FMARD, 2002). Therefore, there is a need for efficient cassava marketing activities which are of key importance for increasing the producers' incomes and for agricultural and economic development (RUSEP, 2002).

Markets play a central role in food security, income generation and rural development. Over the years, laudable progress has been made by agricultural research and development organizations on escalating agricultural productivity. However, in agriculture, in order for productivity-based growth to translate into the well-being of farmers, market opportunities need to be extended (Diao and Hazell, 2004). Furthermore, matters of concern for small-holder farmers are not only agricultural productivity but also a better access to markets (IFAD, 2003).

$\bowtie \mathrm{PhD}$ Adekemi Obisesan, Department of Agricultural and Resource Economics, School of Agriculture and Agricultural Tech-
nology, Federal University of Technology, Akure, P.M.B. 704, Akure, Ondo State, Nigeria, e-mail: kemi_triumph@yahoo.com 
In most African countries, including Nigeria, the food crop marketing system is inefficient (Renkow et al., 2004), as illustrated by the glut in the Nigerian cassava market. Farmers find it difficult to dispose off their produce at attractive prices and places of their choice. According to Holloway et al. (2000), the inability to access markets is a major constraint to improving the welfare of smallholders. It is therefore imperative to understand how farming households can best increase their income and other livelihood outcomes such as food security through better links with markets (Rosegrant et al., 2005). It has been noted that effective market participation considerably contributes to combating food insecurity in the national economy (Rosegrant et al., 2005).

In Nigeria, food poverty incidence increased from $33.6 \%$ in 2004 to $41 \%$ in 2010 while the urban and rural food poverty incidence stood at $26.7 \%$ and $48.3 \%$, respectively (NBS, 2012). It is therefore paradoxical that food insecurity is far more concentrated in rural areas where food is produced. Hence, it is vital to investigate how small-scale farming can become more market-oriented in order to benefit the food insecure which constitute a large part of the population.

Although several studies have been conducted both on food marketing (Adenegan et al., 2012; Agwu et al., 2011; Akinlade et al., 2014; Egbetokun and Omonona, 2012; Gani and Adeoti, 2011; Gebremedhin and Jaleta, 2010; Ogbe, 2010) and food security (Oluyole et al., 2009; Otunaiya and Ibidunni, 2014) in Nigeria and other countries, there is still a dearth of studies on the nexus between market participation and food security. In order to fill the gap in the literature, this study investigates market participation and the way it affects food security among cassava farmers in Nigeria. The study attempts to contribute to the improvement of food marketing and security in Nigeria by estimating the extent of market participation, and by determining the food insecurity status and the influence of market participation and other socio-economic factors on food insecurity among cassava farmers in South West Nigeria.

\section{MATERIALS AND METHODS}

The south-western part of Nigeria comprises six states, represents a geographical area extending from $6^{\circ}$ north latitude to $4^{\circ}$ south latitude, and from $4^{\circ}$ west longitude to $6^{\circ}$ east longitude, and has a land area of approximately 114,271 sq. $\mathrm{km}$, representing $12 \%$ of the country's land mass. Agriculture is the dominant economic activity in the states. The mean annual rainfall is $1480 \mathrm{~mm}$ with a mean monthly temperature range of $18-24^{\circ} \mathrm{C}$ during the rainy season and $30-35^{\circ} \mathrm{C}$ during the dry season. The local climate is favorable for the cultivation of crops like maize, yam, cassava, millet, rice, plantains, cocoa, kola nut, coffee, palm produce, cashew, vegetables etc. (NPC, 2006).

\section{Data source and sampling procedure}

A structured questionnaire was used to collect primary data on socio-economic characteristics, membership of associations, cassava production, credit facilities, household food expenditure details and marketing of cassava production. A multistage sampling technique was employed in the selection. The first stage was the random selection of Ondo and Ogun states from the six states in South West Nigeria. The second stage involved the random selection of four Local Government Areas (LGAs) from each state. Afterwards, in the third stage, three communities were randomly selected from each LGA. The final stage involved a random selection of 540 respondents. However, only 387 replies were useful for the analysis due to missing data.

\section{Analytical tools and model}

The data was analyzed using descriptive analysis, the Foster-Greer-Thorbecke (FGT) indices, and Tobit and logit regression models.

Descriptivestatisticssuchasmeans, tables, frequencies and percentages were used for socio-economic variables.

The Tobit model was used to analyze the factors affecting the extent of market participation among cassava farmers in rural Nigeria. Also referred to as 'censored regression model,' the Tobit model is designed to estimate linear relationships between variables when there is either left- or right-censoring in the dependent variable. This model was used because the objective of the study goes beyond participation (a dichotomous variable) and includes the extent of market participation (a continuous variable). The Tobit model, as specified below, is an extension of probit intended for continuous variables:

$Y^{*}=\beta_{i} X_{i}+\mu_{i}$
with: $\mathrm{Yi}^{*}=M P I=\frac{\sum_{k=1}^{k} \bar{P}_{k} S_{i k}}{\sum_{k=1}^{k} \bar{P}_{k} Q_{i k}}$; the market participation 
index (MPI) is defined as the proportion of the value of crop sales to total value of crop production in the last planting season; $S_{i k}$ is the quantity of output $k$ sold by household $i$ evaluated at an average price $\left(P_{k}\right) ; Q_{i k}$ is total quantity of output $k$ produced by household $i$ (von Braun et al., 1994); $\beta_{i}$ is the vector of parameters to be estimated; $X_{i}$ is the set of explanatory variables; and $\mu$ is the error term.

Explanatory variables: gender, age, marital status, household size, years of education, primary occupation, off-farm income source, membership of farmers' group, area of land cultivated, years of experience, transportation cost, crop yield, access to market information and access to credit.

\section{Foster, Greer and Thorbecke (FGT)}

Following the adoption of Foster-Greer-Thorbecke (FGT) poverty metrics (Foster et al., 1984), the households' per capita equivalent expenditure on food was used to determine the households' food insecurity status in Nigeria (Omonona and Agoi, 2007).

This is defined as:

With:

$$
P_{\alpha}=\frac{1}{N} \sum_{i=1}^{q} G i
$$

$$
G i=\left[\frac{Z-Y}{Z}\right]=\text { food expenditure deficiency of }
$$

household $i$

$$
\text { Head count ratio }(H)=\frac{q}{N}
$$

$Z=$ food security line $(2 / 3$ of the mean per adult equivalent food expenditure); $q=$ number of households below the food security line; $N=$ total number of households in the total population; $Y_{i}=$ per capita equivalent food expenditure of household $i ; \alpha=$ degree of food insecurity aversion; with $\alpha=0$, the measure reflects the food insecurity rate; with $\alpha=1$, the measure reflects the depth of food insecurity; with $\alpha=2$, the measure reflects the severity of food insecurity.

Logit model: this was also used to examine the determinants of food insecurity among cassava farmers. The model is specified below:

$$
\text { Logit } P(Y)=\alpha+\sum \beta_{i} X_{i}
$$

With: $Y_{i}=1$ means success i.e. the household is food insecure, and $Y_{i}=0$ means failure, i.e. the household is food secure; $\alpha=$ constant term; $X_{i}=$ independent variable; $\beta=$ logistic coefficient for independent variables.
Explanatory variables: gender, age, household size, years of education, primary occupation, household income, participation in non-farming activities, distance to the nearest market, membership of a farmers' group, area of land cultivated, years of experience, extent of market participation, crop yield, market information access, access to credit.

\section{RESULTS AND DISCUSSION}

\section{Socio-economic characteristics of respondents}

There was variation in the socio-economic characteristics of the respondents (Table 1). In the study area, male

\begin{tabular}{|c|c|c|}
\hline Characteristics & $\begin{array}{l}\text { Categories/ } \\
\text { statistics }\end{array}$ & Percentage \\
\hline 1 & 2 & 3 \\
\hline \multicolumn{3}{|l|}{ Gender } \\
\hline & Female & 23.27 \\
\hline & Male & 76.73 \\
\hline & Total & 387 \\
\hline \multicolumn{3}{|l|}{ Household size } \\
\hline & $1-4$ & 21.17 \\
\hline & $5-9$ & 72.63 \\
\hline & $>9$ & 6.20 \\
\hline & Total & 387 \\
\hline & Mean & 6 \\
\hline & SD & 1.9759 \\
\hline \multicolumn{3}{|l|}{ Age } \\
\hline & $\leq 30$ & 9.605 \\
\hline & $31-40$ & 28.17 \\
\hline & $41-50$ & 36.29 \\
\hline & $>50$ & 25.94 \\
\hline & Total & 387 \\
\hline & Mean & 44.73 \\
\hline & SD & 10.4317 \\
\hline
\end{tabular}
respondents represent the majority of cassava farmers,

Table 1. Distribution of respondents by socio-economic characteristics 
Table 1 - cont.

\begin{tabular}{|c|c|c|}
\hline 1 & 2 & 3 \\
\hline \multicolumn{3}{|c|}{ Level of education } \\
\hline & No formal & 30.88 \\
\hline & Primary & 44.05 \\
\hline & Secondary & 25.07 \\
\hline \multicolumn{3}{|l|}{ Credit access } \\
\hline & Yes & 65.38 \\
\hline & No & 34.62 \\
\hline \multicolumn{3}{|c|}{ Years of experience in cassava farming } \\
\hline & $\leq 5$ & 8.14 \\
\hline & $6-10$ & 14.74 \\
\hline & $11-15$ & 31.24 \\
\hline & $16-20$ & 30.26 \\
\hline & $>20$ & 15.61 \\
\hline & Total & 387 \\
\hline & Mean & 16.01 \\
\hline & SD & 10.45 \\
\hline \multicolumn{3}{|c|}{ Area of land cultivated (ha) } \\
\hline & $\leq 0.5$ & 22.75 \\
\hline & $0.6-1.0$ & 55.33 \\
\hline & $1.1-1.5$ & 21.92 \\
\hline & Total & 387 \\
\hline & Mean & 1.09 \\
\hline & SD & 0.48 \\
\hline \multicolumn{3}{|c|}{ Non-farming activity } \\
\hline & Yes & 70.46 \\
\hline & No & 29.55 \\
\hline
\end{tabular}

Source: own elaboration.

which may be explained by the tedious nature of cassava production. The average household size was six. The age distribution of the respondents showed that most of them were below 51 years old while the mean age was 44.73. This means that a good proportion of the respondents are in their economically active years. The mean farm size was 1.09 ha, implying that cassava farmers are smallholders. The average period of cassava farming experience was 16 years. As shown by the population's distribution by educational status, $44.78 \%$ of the household heads had primary education while $30.88 \%$ and $25.07 \%$ had no formal education or had secondary education, respectively. The majority $(65.38 \%)$ of respondents had access to credit while $70.46 \%$ were engaged in non-farming activities. The average cassava yield was 13.76 tons/ha. The extent of commercialization among cassava farmers in rural Nigeria was 0.56 which is a medium-high level.

\section{Correlates of market participation extent}

As shown by the estimates of the Tobit regression model in Table 2, the log likelihood was significant, indicating that the model fits the data well. The coefficient of age was negative and significant $(p<0.1)$. This implies that as farmers advance in age, their market participation decreases. The above is consistent with the findings of Egbetokun and Omonona (2012) that an increase in age reduces the farmers' participation in food markets in Ogun State, Nigeria. Because older farmers are less energetic than younger ones, this may have an effect on their output and on the volumes they make available for sale. The results suggest that a unit increase in age will decrease the extent of commercialization by $0.27 \%$. The education level has a positive and significant $(p<0.01)$ influence on the extent of market participation. The results show that a unit increase in the education level will increase market participation by $7.28 \%$. The education enhances the farmers' access to market information and improves their ability to make meaningful decisions on how and when to sell their produce. The above agrees with the conclusions of Akinlade et al. (2014) who found that education increases the farmers' market participation in Nigeria.

Participation in off-farm income generating activities increased the extent of commercialization by $9.71 \%$ (significantly at $1 \%$ ). The farmers engage in non-farming activities, thereby earning additional income which can be employed in farming to increase production and enhance market participation.

Furthermore, the 'years of farming experience' have a positive and significant $(p<0.1)$ effect on the extent of commercialization. A unit increase in the years of farming experience will increase market participation by 0.0000763. This finding is consistent with Egbetokun and Omonona (2012) who concluded that an increase in years of farming experience resulted in an increased market participation among farmers in Ogun State, Nigeria. The membership of a farmers' group significantly 
Table 2. Estimates of Tobit regression for the determinants of the extent of market participation

\begin{tabular}{lccc}
\hline \multicolumn{1}{c}{ Variables } & Coefficients & Standard error & $T$-value \\
\hline Gender & 0.06042 & 0.0414 & 1.46 \\
Age & $-0.00273^{*}$ & .001589 & -1.76 \\
Marital status & 0.00256 & .00159 & 1.60 \\
Household size & 0.0049 & .0092 & 0.53 \\
Education level & $0.0728^{* * *}$ & 0.0205 & 3.55 \\
Primary occupation & 0.0024 & 0.0044 & 0.55 \\
Off-farm activity participation & $0.0971^{* * *}$ & 0.0248 & 3.91 \\
Years of experience & $0.0000763^{*}$ & 0.0000404 & 1.89 \\
Land area cultivated & 0.0377 & 0.0305 & 1.24 \\
Membership of a farmers' group & $0.0863^{* * *}$ & 0.0323 & 2.67 \\
Access to credit & 0.0397 & 0.0304 & 1.30 \\
Transportation cost & $-0.1589^{* * *}$ & 0.0553 & 2.87 \\
Market information access & $-0.0563^{*}$ & 0.0317 & 1.76 \\
Cassava yield & -0.0248 & 0.0437 & 0.58 \\
Constant & $-0.7984^{* * *}$ & 0.1702 & 4.69 \\
Sigma & 0.2750 & & \\
\hline
\end{tabular}

$* * *, * * *$ represents $1 \%, 5 \%$ and $10 \%$ significance levels, respectively.

Source: own elaboration.

$(p<0.01)$ increased the extent of commercialization by $8.63 \%$. Members of an association are provided with the opportunity to participate in group marketing, may access information relevant to their production and marketing decisions, and increase their bargaining power. This finding supports the conclusions of Adenegan et al. (2012) and Akinlade et al. (2014) that the membership of an association improves market participation among Nigerian farmers.

Transportation costs have a significant $(p<0.01)$ but negative effect on market participation. Thus, a reduction in transportation costs will increase market participation rates. The result suggests that a unit increase in transportation costs will reduce the extent of commercialization by $15.89 \%$. As shown by the results, access to market information significantly $(p<0.1)$ increased the extent of commercialization by $5.63 \%$. This finding is in line with the conclusions made by Adenegan et al. (2012).

\section{FOOD INSECURITY STATUS AND ITS DETERMINANTS}

The Mean Per Capita Household Food Expenditure (MPCHHFE) was NGN 30,198.34. The food insecurity line, calculated as two thirds of MPCHHFE, was NGN 20,132.22 per annum. With the food insecurity line being set at this level, $61.53 \%$ of farmers were food insecure.

The results of the Logit model (Table 3) suggest that the extent of market participation was one of the factors with significant negative impact on food insecurity (at $\mathrm{p}<0.05)$. A unit increase in the farmer's extent of market participation will make food insecurity less probable by 0.15 . An increase in extent of commercialization will result in increasing the household's income, thereby improving its food security status. The gender of the household head is significant $(p<0.01)$ but also has a negative effect. Having a male household head 
Table 3. Estimates of the logit regression model

\begin{tabular}{lccc}
\hline \multicolumn{1}{c}{ Variables } & Coefficients & Standard error & -value \\
\hline Gender & $-0.0317^{* * *}$ & 0.0052 & -6.01 \\
Age & -0.0366 & 0.2229 & -1.61 \\
Household size & $0.2716^{*}$ & 0.1567 & 1.73 \\
Level of education & -0.2258 & 0.2449 & 0.92 \\
Primary occupation & $1.8752^{* *}$ & 0.8280 & 2.26 \\
Off-farm activity & $-0.7501^{*}$ & 0.4399 & -1.71 \\
Distance to market & 0.2175 & 0.7074 & 0.31 \\
Years of experience & -0.000527 & 0.00049 & -1.07 \\
Market participation & $-0.1500^{* *}$ & 0.0628 & -2.39 \\
Land area cultivated & 0.4372 & 0.3464 & 1.26 \\
Membership of a farmers' group & -0.1834 & 0.1759 & -1.04 \\
Access to credit & $-0.1564^{* *}$ & 0.0689 & -2.27 \\
Household income & $-0.2510^{*}$ & 0.1428 & -1.76 \\
Market information access & $-0.4787^{*}$ & 0.2655 & -1.80 \\
Cassava yield & $-0.0001928^{* * *}$ & 0.0000237 & -8.14 \\
Constant & $-0.1237^{* * *}$ & 0.2814 & 4.40 \\
Sigma & 0.2310 & & \\
LR chi2 & 30.041 & & \\
Prob $>$ Chi2 & 0.0000 & & \\
R 2 & 0.7957 & & \\
Log likelihood & -101.94 & & \\
\hline & & & \\
\hline & & & \\
\hline
\end{tabular}

***,**,* represents $1 \%, 5 \%$ and $10 \%$ significance levels, respectively.

Source: own elaboration.

reduced the probability of being food insecure by 0.0317 . This might be due to the fact that male farmers have better access to resources than their female counterparts. Moreover, the household size has a significant $(p<0.1)$ and positive effect on food insecurity. The result shows that a unit increase in the household size will increase the probability of being food insecure by 0.2716 . This finding could be explained by an increase in the dependency ratio of large households, and is consistent with the conclusions made by Oluyole et al. (2009) and Otunaiya and Ibidunni (2014) that a large household size increases the probability of food insecurity in Nigeria.
Access to credit facilities is significant $(p<0.05)$ and has a negative effect. As shown by the results of this study, credit access makes food insecurity less probable by 0.1560 . This is because access to credit improves the farmers' economy to adopt new technologies and purchase necessary inputs leading to higher cassava yields, thereby improving their income. Furthermore, the amount of credit granted could also be used to finance the household's food consumption, thus reducing the levels of household food insecurity. According to Otunaiya and Ibidunni (2014), the amount of food bought on credit would increase the probability of food security 
for rural farming households in Ogun state, Nigeria. Off-farm income sources have a negative and significant $(p<0.1)$ impact on food insecurity. The results suggest that non-farming activities will reduce the likelihood of being food insecure by 0.7501 . Farmers who engage in such activities improve their financial standing to acquire inputs employed in cassava production, thereby increasing their output. Also, this is a way to improve their economic access to food. This above is consistent with the findings of Omotesho et al. (2006) that having an off-farm source of income would improve the food security status of rural farming households in Kwara state, Nigeria.

Access to market information significantly $(p<0.1)$ and negatively affects food insecurity. As shown by the results, access to market information decreased the probability of food insecurity by 0.4787 . This could be due to the fact that market information helps farmers realize where their produce can be sold at better price, thereby increasing household income. Furthermore, the increase in cassava yield significantly $(p<0.01)$ decreased the likelihood of being food insecure. The result indicate that a unit increase in cassava yield will reduce the probability of food insecurity by 0.0019 .

\section{CONCLUSION}

Cassava farmers demonstrate a medium-high extent of market participation which is significantly influenced by education level (0.0728), engagement in off-farm activities (0.0971), membership of an association (0.0863), number of years of experience (0.00076), access to market information (0.0563), age $(-0.0027)$ and transportation cost $(-0.0189)$. There is a high incidence of food insecurity among cassava farming households. Having a male headed household reduced the probability of food insecurity. Also, food insecurity is influenced by the extent of market participation $(-0.1500)$, gender $(-0.0317)$, primary occupation $(1.875)$, access to credit $(-0.1564)$, engagement in off-farm activities $(-0.7501)$, yields $(-0.00019)$, household incomes $(-0.2510)$, access to market information $(-0.4787)$ and household size (0.2716). Therefore, the government and other stakeholders should devote attention to factors that could increase market participation and food security among farming households. Note also that gender sensitivity should be integrated into the national food security strategies.

\section{REFERENCES}

Adenegan, K. O., Adepoju, A., Nwauwa, L. O. E. (2012). Determinants of market participation of maize farmers in rural Osun State of Nigeria. Int. J. Agric. Econ. Rural Dev., 5(1), 28-39.

Agwu, N. M., Anyanwu, C. I., Mendie, E. I. (2011). Socioeconomic determinants of commercialization among smallholder farmers in Abia State, Nigeria. Green. J. Agric. Sci., 2(8), 392-397.

Akinlade, R. J., Balogun, O. L., Obisesan, A. A. (2014). Commercialization of urban vegetable farming. Int. J. Veget. Sci., 22(1). DOI: 1080/19315260.2014.921266

von Braun, J., Bouis, H., Kennedy, E. (1994). Conceptual framework. In: J. von Braun, E. Kennedy (Eds.). Agricultural commercialization, economic development, and nutrition, Baltimore, Md., USA: Johns Hopkins University Press for the International Food Policy Research Institute.

Diao, X., Hazell, P. (2004). Exploring market opportunities for African smallholders. Paper prepared for the 2020 Africa Conference "Assuring food security in Africa by 2020: Prioritizing actions, strengthening actors, and facilitating partnerships". Kampala, Uganda. April 1-3, 2004.

Egbetokun, O. A., Omonona, B. T. (2012). Determinants of farmers participation in food market in Ogun State. Global J. Sci. Front. Res. Agric. Vet. Sci., 12(9), 24-30.

Federal Ministry of Agriculture and Rural Development (FMARD) (2002). Agriculture in Nigeria: Policy (before and now) analysis of the existing (1988) agricultural policy and the revised policy. Federal Ministry of Agriculture and Rural development, Abuja.

Food and Agriculture Organization (FAO) (2013). Trend of cassava production in Nigeria. Retrieved from: http:// www.fao.org/faostat/en/

Foster, J., Greer, J., Thorbecke, E. (1984). A class of decomposable poverty measures. Econometrica, 52, 761-766.

Gani, B. S., Adeoti, A. I. (2011). Analysis of Market participation and rural poverty among farmers in northern part of Taraba State, Nigeria. J. Econ., 2(1), 23-36.

Gebremedhin, B., Jaleta, M. (2010). Commercialization of smallholders: Is participation enough? Being a contributed paper presented at the Joint 3rd African Association of Agricultural Economists (AAAE) and 48th Agricultural Economists Association of South Africa (AEASA) Conference, Cape Town, South Africa, September 19-23, 2010.

Holloway, G., Nicholson, C., Delgado, C., Staal, S., Ehui, S. (2000). Agroindustrialization through institutional Innovation. Transaction costs, cooperatives and milk-market development in the East African Highlands. Agric. Econ., 
23(1), 279-288. Retrieved from: https://ageconsearch. umn.edu/bitstream/176215/2/agec2000v023i003a008.pdf

IFAD (2002). Rural poverty report 2002: The challenge of ending rural poverty. Rome, Italy: International Fund for Agricultural Development. Retrieved from: www.ifad. org/poverty/index.htm

IFAD (2003). Promoting market access for rural poor in order to achieve the millennium development goals. Paper presented in Seminar on the 25th anniversary session of governing counci. Rome, Italy, April 16 to 18. Rome: International Fund for Agricultural Development.

IITA (2003). Farming system. International Institute of Tropical Agriculture, Nigeria.

International Fund for Agricultural Development (IFAD). (2010). Investing in rural people. International Fund for Agricultural Development, Via Paolo di Dono 4400142 , Rome, Italy.

National Population Census (NPC). 2006. National Bureau of Statistics Official Gazette (FGP 71/52007/2,500 (OL24) Abuja. Retrieved from: http://www.nigerianstat.gov.ng

NBS (2012). Nigeria Poverty Profile. Abuja: National Bureau of Statistics.

Nweke, F. I., Spencer, D. S. C., Lynam, J. K. (2001). The cassava transformation: Africa's best kept secret. Michigan State University Press, East Lansing.

Ogbe, S. E. (2010). Determinants of microcredit and microfinance outreach to farmers in Abia State: A case study of national special programme on food security. Unpublished M.Sc. Thesis, Dept. Agr. Econ., Michael Okpara Univ. Agr., Umudike, Nigeria.
Oluyole, K. A., Oni, O. A., Omonona, B. T., Adenegan, K. O. (2009). Food security among cocoa farming households of Ondo State Nigeria. ARPN J. Agric. Biol. Sci., 4(5), 2-13.

Omonona, B. T., Agoi, G. A. (2007). An analysis of food security situation among Nigerian urban households: Evidence from Lagos State, Nigeria. J. of Central Europ. Agric., 8(3), 397-406.

Omotesho, O. A., Adewumi, M. O., Muhammad-Lawal, A., Ayinde, O. (2006). Determinants of food security among rural farming households in Kwara State, Nigeria. Afr. J. Gen. Agric., 2(1), 7-15. Retrieved from: https://www. researchgate.net/publication/268371689_Determinants of_Food_Security_Among_The_Rural_Farming_Households_in_Kwara_State_Nigeria

Otunaiya, A. O., Ibidunni, O. S. (2014). Determinants of food security among rural farming households in Ogun State, Nigeria. J. Sust. Dev. Afr., 16 (2), 33-44.

Renkow, M., Hallstrom, D. G., Karanja, D. (2004). Rural infrastructure, transactions costs and market participation in Kenya. J. Dev. Econs., 85(5), 1140-1146.

Rosegrant, M. W., Cline, S. A., Li, W., Sulser, T. B., Velmonte-Santos, R. A. (2005). Looking ahead. Long-term Prospects for Africa's Agric. Paper presented in a Seminar on 2020 Development and Food Security in Washington, D.C., November 12 to 15, 2005.

Rural Sector Enhancement Programme (RUSEP, 2002). Proceedings of National Stakeholders Workshop on Rural Development. IITA Publication, Ibadan, Nigeria. 